
February 1946

\title{
REPRODUCIBILITY OF THE LEAD ELECTRODE AND THE ELECTROMOTIVE FORCE OF THE LEAD STICK-LEAD AMALGAM CELL AT $0^{\circ}$ TO $60^{\circ} \mathrm{C}$
}

\author{
By Roger G. Bates, Murray Edelstein, and S. F. Acree
}

\section{ABSTRACT}

The potentials of four types of solid lead electrodes with respect to saturated lead amalgam were obtained. Although lead anneals spontaneously, the surface condition has a profound effect upon the electromotive force. Untreated lead sticks were, in general, positive to lead the surface of which had been rendered strain-free. When etched in a mixture of nitric acid and lead nitrate, these lead sticks soon reached the same potential. Removal of air from the solutions improved the agreement among the electrodes.

Twelve sticks cast from National Bureau of Standards Standard Sample 49b and twelve cast from "spectroscopically pure" lead were etched and used to determine the difference of potential between stick lead and 8-percent lead amalgam at intervals of 5 degrees from $0^{\circ}$ to $60^{\circ} \mathrm{C}$. The results are given by the equation

$$
E=0.005347+0.0000201 t,
$$

where $E$ is the electromotive force in international volts and $t$ is in degrees centigrade. Thermodynamic constants were computed from the temperature coefficient of electromotive force. No difference was found between the two kinds of lead.

\section{CONTENTS}

I. Introduction

II. Reproducibility of the lead electrode

1. Materials_............. 161

2. Effect of surface condition on the potentials of lead electrodes_- 162

3 . Effect of air on the potentials of lead electrodes_............ 164

4. Comparison of various types of lead electrodes ............ 165

III. Electromotive force between lead sticks and saturated lead amalgam at $0^{\circ}$ to $60^{\circ} \mathrm{C}$

1. Experimental procedures and results

2. Thermodynamic constants for lead and lead amalgam

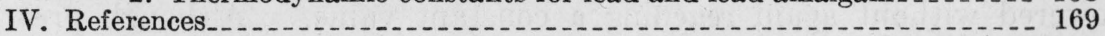

\section{INTRODUCTION}

Although the lead electrode has been the subject of a number of published investigations, its reproducibility and suitability for use in electromotive-force studies over a range of temperatures have not been clearly defined. In 1910, Lewis and von Ende [1] ${ }^{1}$ wrote “ . . . all solid metals (give) an inconstant potential owing to uncontrollable surface variations." When a highly reproducible electrode reversible to a metallic ion is required, it has usually been necessary to use

\footnotetext{
1 Figures in brackets indicate the literature references at the end of this paper.
} 
amalgams. As a fairly soft metal, however, pure lead should readily lose the strains responsible for the erratic thermodynamic behavior of other harder metals. Inasmuch as reference electrodes reversible to bivalent anions can be used advantageously in certain types of electrometric $\mathrm{pH}$ work, and the lead-lead sulfate electrode appears to be the most suitable representative of this class, further studies of lead electrodes were undertaken. Furthermore, the lead electrode, together with the slightly soluble lead salts of weak acids, might be used to advantage in studies of the activity of these acids and their soluble salts in aqueous solution.

Active surface areas can sometimes be rendered strain-free, and reproducible electrodes obtained, by subjecting the metal to slow etching in acid for several days [2]. However, when Heller and others $[3,4,5]$ immersed lead sticks in solutions of lead acetate to which nitric acid had been added, the metal was found to disintegrate slowly until only a gray powder remained. Electrolysis of lead sticks in nitric acid produced a similar deterioration [6]. This evidence of the existence of two or more allotropic forms of lead appeared to be confirmed by measurements of density [4]. In their study of the lead electrode, Lewis and Brighton [7] failed to find evidence of allotropism, and later work by Rawdon [8] led to the conclusion that the forms previously described as allotropic were only a granular condition of the ordinary form brought about by intercrystalline embrittlement. The impurities commonly occurring in lead are insoluble in the solid state and are found lodged between the grains of lead. Embrittlement is largely due to the behavior of these impurities when the metal is immersed in electrolyte. This conclusion was supported by the work of Thiel [9].

Gerke [10] measured the differences of potential between 5-percent lead amalgam and two electrodes formed of electrolyzed lead crystals in 1- $M$ lead acetate at temperatures from $5^{\circ}$ to $45^{\circ} \mathrm{C}$. The potentials of four lead sticks, two of them immersed in a solution of lead acetate and two in lead perchlorate, were also measured between $20^{\circ}$ and $50^{\circ}$ C. The mean emf at $25^{\circ} \mathrm{C}$ was $0.0057 \mathrm{v}$. No statement was made concerning the method of preparing the lead sticks. The thermodynamic properties of electrolyzed crystals and of sticks appeared to be different. Carmody [11] found that five scraped sticks free of physical defects gave an average emf of $0.00584 \pm 0.00002 \mathrm{v}$ at $25^{\circ} \mathrm{C}$ with respect to a saturated lead amalgam. He observed that ". . . the potential was constant for about two hours. After this time a gray coating formed on the surface of the stick and the potential slowly lowered without again reaching a constant value." Although precautions had been taken to remove air from the solution of lead chloride, this observation suggests that traces of oxygen were actually present and were reacting at the surface of the lead, with the ultimate formation of basic lead salts. It seems likely that the susceptibility of the emf to oxygen can be diminished somewhat by the use of electrolytes containing high concentrations of lead ion and enough free acid to prevent the deposition of slightly soluble basic salts.

The number of lead electrodes studied has been insufficient to furnish a clear picture of the effect of surface treatment, air, and temperature changes upon the potential. In this investigation, sticks cast from NBS melting-point lead and from a sample of spectroscopically pure lead were etched with acid until further treatment caused 
no change in potential. Twenty-four electrodes were then selected, and emf measurements with respect to saturated lead amalgams were made at intervals of 5 degrees from $0^{\circ}$ to $60^{\circ} \mathrm{C}$.

\section{REPRODUCIBILITY OF THE LEAD ELECTRODE}

The potentials of electrodes treated in various ways were measured at room temperature with respect to each other and to saturated lead amalgams. For this comparison, the electrodes were usually immersed in a $0.05-M$ solution of lead acetate containing sufficient nitric acid to discharge the turbidity. These comparisons were usually made in 1-liter flasks, that accommodated seven rubber stoppers. Twelve electrodes could thus be measured against the same amalgam.

\section{MATERIALS}

Reagent grades of lead acetate, lead carbonate, perchloric acid, and nitric acid were used without further purification. The mercury, stated to have a purity greater than 99.999 percent, was supplied by the Reagents and Platinum Metals Section of this Bureau. The nitrogen was purified by passage over soda-lime and over finely divided copper heated to $500^{\circ} \mathrm{C}$.

Two samples of lead were used. The first was NBS Standard Sample $49 \mathrm{~b}$, which has a melting point of $327.4_{0}^{\circ} \mathrm{C}$. The second was obtained from the laboratories of the American Smelting \& Refining Co., Perth Amboy, N. J. Spectroscopic examination was said to reveal no impurity other than a trace of iron.

Lead amalgam, containing 8 percent of lead by weight, was used in all the work. Two amalgams, one prepared from each of the two samples of lead, were found to give the same potential, within experimental error. The NBS Standard Sample of lead was used in preparing the amalgam for all subsequent measurements. An analysis of the phase studies of Puschin [12] for the lead-mercury system indicated that an 8-percent amalgam consists of two phases between $0^{\circ}$ and $60^{\circ}$ C. Lead amalgam that contains 5 percent of lead has found most general use heretofore for emf measurements, even at temperatures as high as $50^{\circ} \mathrm{C}[10,13]$, although one of the writers [14], in a study of solutions of lead bromide at temperatures from $5^{\circ}$ to $40^{\circ} \mathrm{C}$, found desirable the employment of a 10-percent amalgam. Puschin did not indicate as high accuracy for the freezing points of amalgams which contained less than 10 atom percent of lead as for those richer in lead, but it seems evident that the solid phase persists in an 8-percent amalgam to a temperature of $80^{\circ} \mathrm{C}$. Haring, Hatfield, and Zapponi [15] found that lead is soluble in mercury to the extent of 0.0165 atom fraction (1.7 percent by weight) at $25^{\circ} \mathrm{C}$.

The amalgam was prepared by heating together weighed quantities of stick lead and mercury in a small beaker at a temperature sufficiently high to insure homogeneity of the resulting amalgam. It was stored in the amalgam pipette shown in figure 1, in which it could be melted and from which it could be withdrawn into the evacuated cell vessels. The pipette was heated to $100^{\circ} \mathrm{C}$ in an oven before charging it with amalgam. It was then evacuated with an oil pump and the hot amalgam drawn in through stopcock $b$, care being taken to leave the dross behind. When the pipette bad cooled to room temperature, 
the vacuum was broken with pure nitrogen by rotating stopcock $a$ through $180^{\circ}$.

Four types of lead electrodes were prepared. (1) The metal was melted in an alundum crucible and poured into glass or polystyrene tubes, fitted into holes in a graphite block (see fig. 1). Usually the ends of the stick were exposed and a portion of the glass or plastic left in the form of a sleeve over the electrode where it passed through the stopper in which it was later supported. (2) A few electrodes were prepared by electrolytic deposition of lead on platinum foils sealed in glass. The metal was obtained in a macrocystalline form from a solution of lead acetate, or as a smooth deposit from a solution of lead

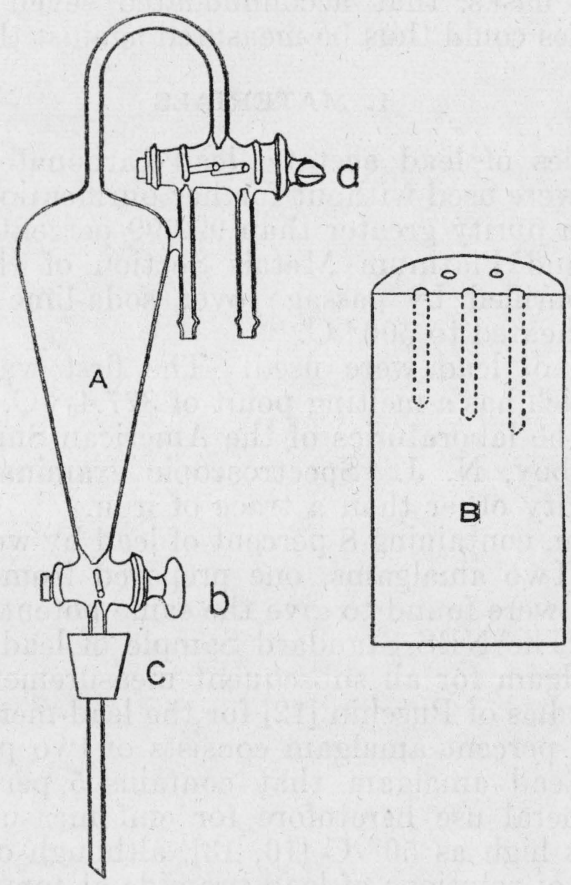

FIGURE 1.-Amalgam pipette $(A)$ and graphite block $(B)$ in which the stick electrodes were cast.

fluoborate furnished by the Electrochemistry (Plating) Section of this Bureau. (3) Lead sticks, $6 \mathrm{~mm}$ in length and $5 \mathrm{~mm}$ in diameter, were fused to platinum wires which, in turn, were sealed into short lengths of glass tubing. (4) Lead was cast in the graphite block shown in figure 1 to form sticks $7.5 \mathrm{~cm}$ in length and $5 \mathrm{~mm}$ in diameter. All four types of electrodes were mounted in pairs in rubber stoppers for subsequent treatment and study.

\section{EFFECT OF SURFACE CONDITION ON THE POTENTIALS OF LEAD ELECTRODES}

It is well known that lead, hardened by cold-working, anneals itself spontaneously at room temperature. Slightly deformed samples are the slowest to recover, but in most instances annealing is found to be complete in a few hours [16, 17]. It was evident early in this study, 
however, that surface condition had a profound influence upon the potentials of samples of lead. Electrodes whose surfaces appeared smooth and bright usually differed in potential by 0.5 to $2.0 \mathrm{mv}$, or more, from electrodes that showed the dull-gray characteristic of a well-etched lead surface.

Slow attack of the lead surface was found to be desirable. For this purpose, several acidified solutions of lead salts were tried before a mixture $0.2 \mathrm{M}$ in lead nitrate and $0.75 \mathrm{M}$ in nitric acid was selected as the most suitable. The nature of the etching solution was apparently not critical, however. Electrodes that had been etched for a few hours often appeared to be in a stable condition, although several days was usually allowed, with occasional replacement of the etching solution. The rapid initial changes made it impracticable to attempt to follow the potential as a function of the time of etching, as has been done with zinc [2].

The effect of etching 12 lead electrodes of type 3 is shown by the emf values given in table 1 . The electrodes were washed with dilute nitric acid and rinsed. Before etching, the mean potential was 3.12 $\mathrm{mv}$ more negative than the two-phase amalgam with which the electrodes were compared, and the standard deviation ${ }^{2}$ of the mean of the 12 values was $0.27 \mathrm{mv}$. After the electrodes had been treated for 5 hours with dilute nitric acid, the mean emf was found to have risen to $5.84 \mathrm{mv}$, a value close to that found by Gerke [10] and Carmody [11]. The standard deviation of the mean had dropped to $0.07 \mathrm{mv}$. The comparisons were made in an acidified solution of lead acetate. Dissolved oxygen was not removed.

TABLE 1.-Potentials of lead electrodes (type 3) in 0.05-M lead acetate before and after etching for 5 hours in dilute nitric acid; vs saturated lead amalgam at room temperature

\begin{tabular}{|c|c|c|}
\hline Number & Before etching & After etching \\
\hline $\begin{array}{l}1 \\
2 \\
3 \\
4 \\
5 \\
6\end{array}$ & $\begin{array}{r}m v \\
4.74 \\
4.56 \\
2.72 \\
2.80 \\
2.46 \\
3.01\end{array}$ & $\begin{array}{l}m v \\
5.88 \\
5.90 \\
5.97 \\
6.03 \\
6.16 \\
5.88\end{array}$ \\
\hline $\begin{array}{l}7 \\
7 \\
9\end{array} 10$ & $\begin{array}{l}2.60 \\
3.26 \\
3.83 \\
1.22 \\
2.77 \\
3.44\end{array}$ & $\begin{array}{l}5.97 \\
5.90 \\
5.82 \\
5.04 \\
5.78 \\
5.73\end{array}$ \\
\hline $\begin{array}{l}\text { Mean } \\
\text { Standard deviation of the mean }\end{array}$ & $\begin{array}{l}3.12 \\
0.27\end{array}$ & $\begin{array}{l}5.84 \\
0.07\end{array}$ \\
\hline
\end{tabular}

The emf values of 16 stick electrodes classified by visual examination as "well etched," of 7 classified as "poorly etched," and of one bright, new electrode versus saturated amalgam are given in table 2 . The appearance of the electrode was found to provide an adequate index of the progress of the etching.

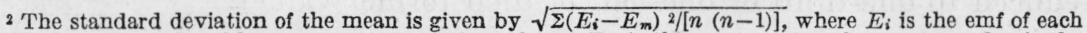
individual electrode with respect to saturated amalgam, $E_{m}$ is the mean emf of the group, and $n$ is the number of observations from which $E_{m}$ is derived. 


\section{Journal of Research of the National Bureau of Standards}

TABLE 2.-Potentials of lead stick electrodes (type 4) with different degrees of etching, in 0.05-M lead acetate at room temperature

\begin{tabular}{|c|c|}
\hline Number & $\begin{array}{l}\text { Electromotive } \\
\text { force versus } \\
\text { saturated } \\
\text { amalgam }\end{array}$ \\
\hline \multicolumn{2}{|l|}{ BRIGHT, UNETCHED STICK } \\
\hline & $\begin{array}{c}m v \\
3.80\end{array}$ \\
\hline \multicolumn{2}{|l|}{ POORLY ETCHED STICKS } \\
\hline \multirow{2}{*}{ Mean. } & $\begin{array}{l}5.52 \\
5.36 \\
5.40 \\
5.43 \\
5.55 \\
5.16 \\
5.19\end{array}$ \\
\hline & 5. 37 \\
\hline \multicolumn{2}{|l|}{ WELL-ETCHED STICKS } \\
\hline 10 & $\begin{array}{l}5.62 \\
5.69 \\
5.68 \\
5.63 \\
5.72\end{array}$ \\
\hline 14 & $\begin{array}{l}6.16 \\
5.64 \\
5.65 \\
5.65 \\
5.70\end{array}$ \\
\hline 19 & $\begin{array}{l}5.66 \\
5.56 \\
5.80 \\
5.56 \\
5.66 \\
5.56\end{array}$ \\
\hline Mean... & 5.68 \\
\hline
\end{tabular}

\section{EFFECT OF AIR ON THE POTENTIALS OF LEAD ELECTRODES}

Nitrogen was chosen in preference to hydrogen for removing dissolved air from the solutions in which lead electrodes were used. The danger of hydrogen polarization at the exposed platinum surfaces of electrodes of types 2 and 3 was thus avoided. Exclusion of air did not exert a large influence on the potential of well-etched electrodes immersed in acidified lead acetate solution but improved the agreement among individual electrodes of a set. Further, it is reasonable to suppose that side reactions were slowed and the life of the cell prolonged.

Table 3 illustrates the effect of passing nitrogen for 2 hours through a solution of lead acetate in which lead electrodes were being compared with a lead amalgam electrode. When most of the air had been replaced by nitrogen, the standard deviations of the means were reduced to one-third or one-half of their former values. 
TABLE 3.-Effect of air on the potentials of lead electrodes in 0.05-M lead acetate at room temperature

\begin{tabular}{|c|c|c|c|c|}
\hline \multirow{3}{*}{ Number } & \multicolumn{4}{|c|}{ Electromotive force versus saturated amalgam, of- } \\
\hline & \multicolumn{2}{|c|}{$\mathrm{Pb}$ sealed to $\mathrm{Pt}$ (type 3 ) - } & \multicolumn{2}{|c|}{ Etched Pb sticks (type 4)- } \\
\hline & $\underset{\substack{\text { In } \\
\text { air-containing } \\
\text { solution }}}{\mid}$ & $\begin{array}{l}\text { After } \\
\text { removal } \\
\text { of air }\end{array}$ & $\underset{\begin{array}{c}\text { In } \\
\text { air-containing } \\
\text { solution }\end{array}}{\mid}$ & $\begin{array}{l}\text { After } \\
\text { removal } \\
\text { of air }\end{array}$ \\
\hline & $\begin{array}{l}m v \\
6.19 \\
6.43 \\
6.26 \\
6.05 \\
5.85\end{array}$ & $\begin{array}{r}m v \\
5.72 \\
5.95 \\
5.85 \\
5.70 \\
5.87\end{array}$ & $\begin{array}{r}m v \\
5.93 \\
5.69 \\
5.71 \\
5.49 \\
5.44\end{array}$ & $\begin{array}{ll} & \\
& \\
& 5.92 \\
5.91 & 5.92 \\
5.85 & 51 \\
5.91\end{array}$ \\
\hline $\begin{array}{l}6 \\
7 \\
\end{array}$ & $\begin{array}{l}5.80 \\
5.52 \\
5.73\end{array}$ & $\begin{array}{l}5.70 \\
5.76 \\
5.81\end{array}$ & $\begin{array}{l}\text { 5. } 28 \\
5.34 \\
5.57 \\
5.30\end{array}$ & $\begin{array}{l}5.91 \\
5.86 \\
5.97 \\
5.61\end{array}$ \\
\hline $\begin{array}{l}\text { Mean } \\
\text { Standard deviation of the mean.............. }\end{array}$ & $\begin{array}{l}5.98 \\
0.10\end{array}$ & $\begin{array}{l}5.80 \\
0.03\end{array}$ & $\begin{array}{l}5.53 \\
0.07\end{array}$ & $\begin{array}{l}5.87 \\
0.03\end{array}$ \\
\hline
\end{tabular}

\section{COMPARISON OF VARIOUS TYPES OF LEAD ELECTRODES}

Of the four types of electrodes studied, lead in stick form (type 4) was found to be the most convenient and reproducible. Type 3, formed of lead sealed to platinum wire, was slightly less satisfactory. Electrodes of this type, and those prepared by the electrolytic deposition of lead upon platinum, frequently gave erratic potentials in the most acid solutions. Reaction of the lead with the acid solution, as a result of the low hydrogen overvoltage of the platinum, was a possible cause of this behavior. Lead deposited from the commercial fluoborate plating solution differed in potential from the purest forms by several tenths of a millivolt, and no further experiments were performed with smooth deposits. Electrolytic crystals appeared to give satisfactory results, but the crystals did not adhere well to the platinum support. Electrodes of type 1 were subject to the objection that the lead did not adhere tightly to the glass or polystyrene sleeve, with the result that etching solution passed into the sleeve and was not removed by subsequent washing.

Inasmuch as the partial free energy of lead in the amalgam is somewhat lower than the free energy of lead in the solid state, the lead electrode is more susceptible to oxidation than is a saturated lead amalgam. Further, sudden temperature changes, as will be seen in the succeeding section, sometimes effect disturbances of potential not found with amalgams. On the other hand, lead electrodes are more convenient to prepare and use than are amalgams and can be used more than once.

\section{ELECTROMOTIVE FORCE BETWEEN LEAD STICKS AND SATURATED LEAD AMALGAM AT $0^{\circ}$ TO $60^{\circ} \mathrm{C}$}

Gerke's study of the difference in potential between pure lead and two-phase amalgam has been extended by measurements with a set of reproducible lead electrodes over the range $0^{\circ}$ to $60^{\circ} \mathrm{C}$. These data yield a comparison of the potential of NBS Standard Sample $49 \mathrm{~b}$ with 
that of lead of nearly spectroscopic purity. They permit, as well, a recalculation of some of the thermodynamic constants for lead and saturated lead amalgam to be made.

\section{EXPERIMENTAL PROCEDURES AND RESULTS}

Lead sticks were cast from NBS Standard Sample 49b and from spectroscopically pure lead. All of them were etched for 1 week. Twelve well-etched sticks of each kind were selected for study.

Six cells of the type shown in figure 2 were employed. A pair of sticks cast from spectroscopically pure lead was rinsed and fixed in place in arm $A$. The amalgam pipette, heated in the oven to $80^{\circ}$ to $100^{\circ} \mathrm{C}$, was adjusted by means of the rubber stopper (c, fig. 1)

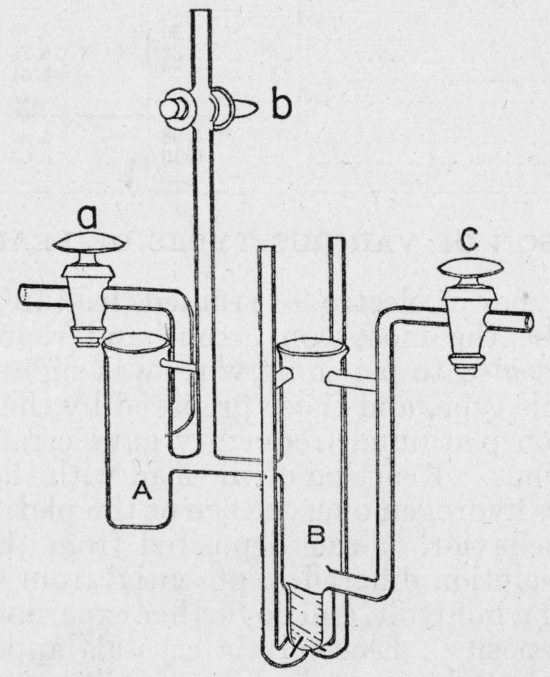

Figure 2.-Cell vessel used for lead and lead amalgam electrodes.

in the other arm $(B)$ of the cell, the vessel evacuated through stopcock $c$, and molten amalgam drawn in to form the two amalgam electrodes at the bottom of $B$. When the amalgam had cooled, enough air-free solution was admitted from the solution flask (attached at $b$ ) to cover it, and the vacuum was then broken by admitting nitrogen through stopcock $a$.

With nitrogen escaping from the top of $B$, the amalgam pipette was replaced by a pair of sticks cast from NBS Standard Sample $49 \mathrm{~b}$. The cell was twice filled completely with electrolyte and emptied through the waste tube at $c$ before the final portion of solution was admitted.

The first three cells contained $0.5-M$ lead perchlorate, prepared from lead carbonate and perchloric acid. The other three were filled with $0.5-M$ lead acetate to which a little acetic acid had been added.

At the outset of the experiments, the two amalgam electrodes in each cell agreed in potential, on the average, to $0.03 \mathrm{mv}$. The results are summarized in table 4 . The emf was observed to increase 
about $0.1 \mathrm{mv}$ for an increase in temperature of 5 degrees. Occasionally, however, one or more electrodes were found to exhibit an increase of as much as five times the normal temperature effect, or even a decrease. This erratic behavior occurred most frequently with the "spectroscopic" lead at the low temperatures. Inasmuch as the abnormal deviations could readily be identified, these questionable observations were rejected.

The individual emf values are plotted in figure 3 as a function of temperature. The open circles represent potentials of electrodes cast from NBS Standard Sample 49b, and the dots represent the emf of sticks of the spectroscopically pure lead. The diameter of

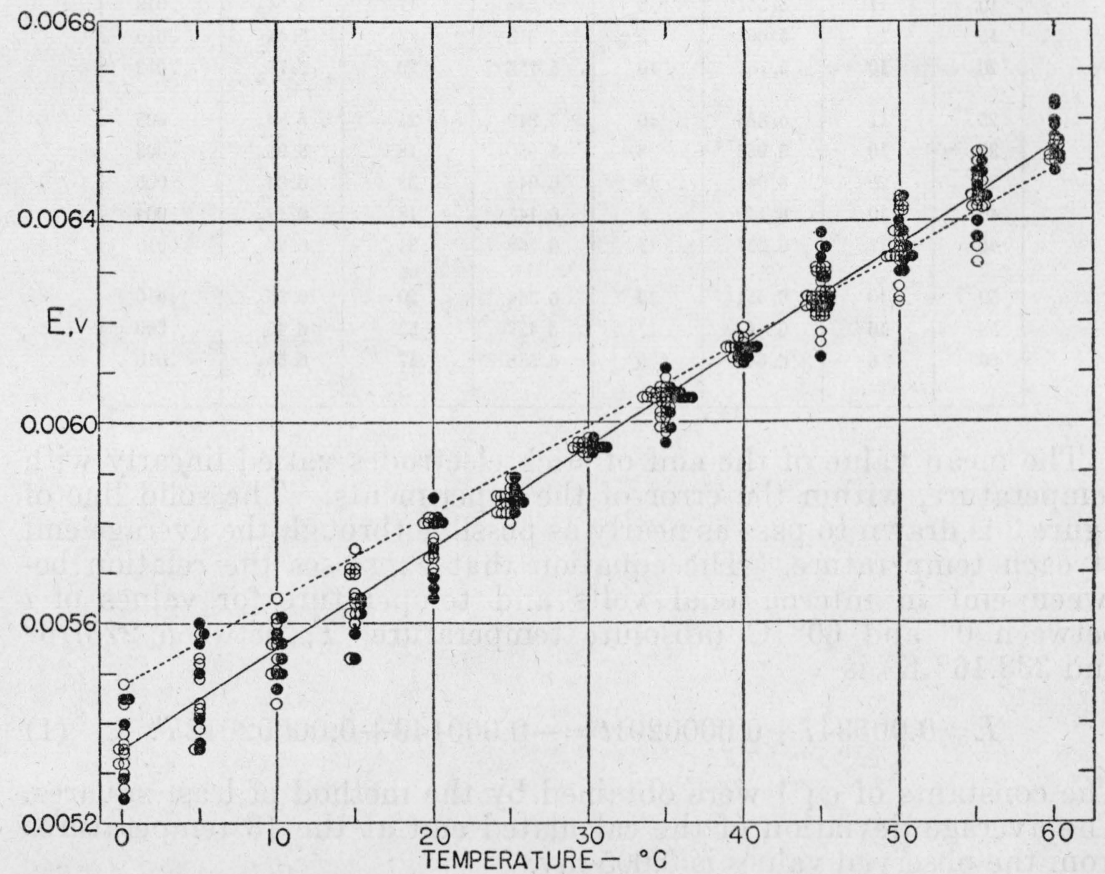

Figure 3.-Electromotive force of the lead stick-lead amalgam cell at $0^{\circ}$ to $60^{\circ} \mathrm{C}$, as a function of temperature.

Open circles represent NBS lead electrodes; dots represent "spectroscopically pure" lead. Diameter of circles corresponds to $0.02 \mathrm{mv}$. The slope of the dotted line differs from that of the solid line by three times the uncertainty assigned to the latter. All the measurements were made at multiples of 5 degrees centigrade. To minimize overlapping, however, some of the points have been plotted slightly to the right or left of the appropriate coordinate line.

each circle corresponds to $0.02 \mathrm{mv}$. It is evident that no real difference exists between lead from the two sources.

The mean emf values at 13 temperatures for the two kinds of lead are given in table 4, together with the over-all mean for all electrodes and the standard deviation. Two observations were recorded for some of the lead sticks at $35^{\circ}, 45^{\circ}$, and $55^{\circ} \mathrm{C}$. These measurements were obtained when a portion of the temperature range was repeated for check. The emf at $25^{\circ} \mathrm{C}, 0.00585$ int $\mathrm{v}$, is in excellent agreement with $0.00584 \mathrm{v}$ found by Carmody [11]. 
TABLE 4.--Electromotive force of the cell: $\mathrm{Pb}$ stick $\left|\mathrm{Pb}^{++}\right| \mathrm{Pb}$ (2-phase amalgam) at $0^{\circ}$ to $60^{\circ} \mathrm{C}$

\begin{tabular}{|c|c|c|c|c|c|c|c|}
\hline \multirow{3}{*}{$t$} & \multicolumn{4}{|c|}{ A verage emf of cells with- } & \multirow{3}{*}{$\begin{array}{c}\text { Total } \\
\text { number } \\
\text { of elec- } \\
\text { trodes }\end{array}$} & \multirow{3}{*}{ Mean emf } & \multirow{3}{*}{$\begin{array}{l}\text { Standard } \\
\text { deviation } \\
\text { of the } \\
\text { mean }\end{array}$} \\
\hline & \multicolumn{2}{|c|}{ NBS lead sticks } & \multicolumn{2}{|c|}{$\begin{array}{l}\text { "Spectroscopic" } \\
\text { lead sticks }\end{array}$} & & & \\
\hline & Number & emf & Number & emf & & & \\
\hline${ }^{\circ} \mathrm{C}$ & 11 & $\begin{array}{l}\text { Int. } m v \\
5.362\end{array}$ & 6 & $\begin{array}{c}\text { Int. mv } \\
\mathbf{5 . 3 3 0}\end{array}$ & 17 & $\begin{array}{l}\text { Int. } m v \\
5.35\end{array}$ & 0.020 \\
\hline 5 & 12 & 5. 437 & 7 & 5.480 & 19 & $5.45_{2}^{1}$ & .021 \\
\hline 10 & 11 & 5.551 & 6 & 5. 538 & 17 & $5.54_{6}$ & .013 \\
\hline 15 & 12 & 5. 651 & 5 & 5. 618 & 17 & 5. $64_{2}$ & .016 \\
\hline 20 & 10 & 5. 763 & 10 & 5.755 & 20 & 5. $75_{9}$ & .013 \\
\hline 25 & 11 & 5.845 & 10 & 5.849 & 21 & 5. $84_{7}$ & .005 \\
\hline 30 & 10 & 5.953 & 8 & 5. 950 & 18 & 5. $95_{2}$ & .003 \\
\hline 35 & 20 & 6.041 & 18 & 6.045 & 38 & 6.041 & .005 \\
\hline 40 & 10 & 6. 149 & 8 & 6. 145 & 18 & 6.147 & .004 \\
\hline 45 & 17 & 6. 257 & 17 & 6. 268 & 34 & 6. $26_{2}$ & .010 \\
\hline 50 & 10 & 6. 351 & 10 & 6. 354 & 20 & 6. $35_{2}$ & .010 \\
\hline 55 & 16 & 6. 443 & 17 & 6.457 & 33 & $6.45_{0}$ & .009 \\
\hline 60 & 8 & 6. 553 & 9 & 6. 558 & 17 & $6.55_{5}$ & .010 \\
\hline
\end{tabular}

The mean value of the emf of stick electrodes varied linearly with temperature, within the error of the experiments. The solid line of figure 3 is drawn to pass as nearly as possible through the average emf at each temperature. The equation that expresses the relation between emf in international volts and temperature for values of $t$ between $0^{\circ}$ and $60^{\circ} \mathrm{C}$ (absolute temperature, $T$, between $273.16^{\circ}$ and $333.16^{\circ} \mathrm{K}$ ) is

$$
E=0.005347+0.0000201 t=-0.000149+0.00002012 T .
$$

The constants of eq 1 were obtained by the method of least squares. The average deviation of the calculated emf at the 13 temperatures from the observed values is $0.005 \mathrm{mv}$.

\section{THERMODYNAMIC CONSTANTS FOR LEAD AND LEAD AMALGAM}

The differences of free energy, $\Delta F$, of entropy, $\Delta S$, and of heat content, $\Delta H$, for the process: $\mathrm{Pb}$ (stick) $=\mathrm{Pb}$ (in saturated amalgam) are expressed in terms of the constants of eq 1 by the equations

$$
\begin{aligned}
& \Delta F=-2(96,500)(-0.000149+0.00002012 T) . \\
& \Delta S=2(96,500)(0.00002012) . \\
& \Delta H=2(96,500)(0.000149) .
\end{aligned}
$$

As a consequence of the linear variation of emf with respect to temperature, $\Delta S$ and $\Delta H$ are independent of temperature. The values of these three thermodynamic constants are given in table 5 . The unit of energy in eq 2, 3, and 4 is the international joule. These quantities were expressed in defined calories by dividing by the conversion factor 4.1833 . 
An estimate of the probable uncertainties in the constants given in table 5 can be made with the use of the standard deviations of the mean emf values listed in table 4, namely, $0.02 \mathrm{mv}$ at $0^{\circ} \mathrm{C}$ and 0.01 $\mathrm{mv}$ at $60^{\circ} \mathrm{C}$. If the error is arbitrarily set at twice that indicated by the standard deviations of these two emf values, the uncertainty of the coefficient of $t$ (or $T$ ) in eq 1 is estimated to be $1 \times 10^{-6}$. In this way, $\Delta F$ is assigned an uncertainty of 5 int. j, whereas $\Delta S$ and $\Delta H$ may be in error by 0.20 int. $\mathrm{j} / \mathrm{deg}$ and 60 int. j, respectively. For comparison, it may be noted that the dotted line of figure 3 differs in slope from the solid line by $3 \times 10^{-6}$, or three times the estimated uncertainty in establishing the slope of the latter.

TABLE 5.-Thermodynamic constants for the process: $\mathrm{Pb}$ (stick) $=\mathrm{Pb}$ (saturated amalgam) at $0^{\circ}$ to $60^{\circ} \mathrm{C}$

\begin{tabular}{|c|c|c|c|c|c|c|c|c|}
\hline$t$ & \multicolumn{2}{|c|}{$-\Delta F$} & $t$ & \multicolumn{2}{|c|}{$\Delta S$} & $t$ & \multicolumn{2}{|c|}{$\Delta H$} \\
\hline $\begin{array}{r}{ }^{\circ} \mathrm{C} \\
0 \\
5 \\
10 \\
15 \\
20\end{array}$ & $\begin{array}{c}\text { Int. } j \\
1,032 \\
1,051 \\
1,071 \\
1,090 \\
1,110\end{array}$ & $\begin{array}{c}c a l \\
247 \\
251 \\
256 \\
261 \\
265\end{array}$ & ${ }^{\circ} \mathrm{C}$ & Int. $j / d e g$ & cal/deg & ${ }^{\circ} \mathrm{C}$ & Int. $j$ & cal \\
\hline $\begin{array}{l}25 \\
30 \\
35 \\
40 \\
45\end{array}$ & $\begin{array}{l}1,129 \\
1,148 \\
1,168 \\
1,187 \\
1,207\end{array}$ & $\begin{array}{l}270 \\
275 \\
279 \\
284 \\
288\end{array}$ & 0 to 60 & 3.9 & 0.93 & 0 to 60 & 29 & 7 \\
\hline $\begin{array}{l}50 \\
55 \\
60\end{array}$ & $\begin{array}{l}1,226 \\
1,245 \\
1,265\end{array}$ & $\begin{array}{l}293 \\
298 \\
302\end{array}$ & & & & & & \\
\hline
\end{tabular}

Gerke [10] found different termperature coefficients of emf for similar cells which contained, on the one hand, electrolyzed lead crystals and, on the other, lead sticks. The thermodynamic quantities at $25^{\circ} \mathrm{C}$ computed by Gerke for the two types of lead are as follows: For electrolyzed crystals, $\Delta F=-263 \mathrm{cal} ; \Delta S=0.97 \mathrm{cal} / \mathrm{deg} ; \Delta H=26$ $\mathrm{cal}$; and for lead sticks, $\Delta F=-263 \mathrm{cal}, \Delta S=0.69 \mathrm{cal} / \mathrm{deg}, \Delta H=-57$ cal. The values computed from cells with electrodes formed of electrolyzed crystals agree well with the values found in this investigation: $\Delta F=-270 \mathrm{cal} ; \Delta S=0.93 \mathrm{cal} / \mathrm{deg} ;$ and $\Delta H=7 \mathrm{cal}$. Gerke removed dissolved air from the solutions but makes no mention of etching the lead sticks. If the sticks were indeed untreated, it seems probable that the crystals represent the more stable modification. This conclusion would lend support to the values given in table 5 .

\section{REFERENCES}

[1] G. N. Lewis and C. L. von Ende, J. Am. Chem. Soc. 32, 732 (1910).

[2] W. J. Clayton and W. C. Vosburgh, J. Am. Chem. Soc. 58, 2093 (1936).

[3] H. Heller, Z. physik. Chem. 89, 761 (1915).

[4] E. Cohen and W. D. Helderman, Verslag Akad. Wetenschappen 17, 822 (1915).

[5] F. H. Getman, J. Am. Chem. Soc. 38, 792 (1916); 10, 611 (1918).

[6] H. J. M. Creighton, J. Am. Chem. Soc. 37, 2064 (1915).

i7] G. N. Lewis and T. B. Brighton, J. Am. Chem. Soc. 39, 1906 (1917).

[8] H. S. Rawdon, Sci. Pap. BS 16, 215 (1920) S377.

[9] A. Thiel, Ber. deut. chem. Ges. 53, 1052, 1066 (1920).

[10] R. H. Gerke, J. Am. Chem. Soc. 44, 1684 (1922). 


\section{Journal of Research of the National Bureau of Standards}

[11] W. R. Carmody, J. Am. Chem. Soc. 51, 2905 (1929).

[12] N. A. Puschin, Z. anorg. Chem. 36, 14 (1903).

[13] M. C. Hannan, Dissertation, The Catholic University of America (1936).

114] R. G. Bates, J. Am. Chem. Soc. 64, 1136 (1942).

[15] M. M. Haring, M. R. Hatfield, and P. P. Zapponi, Trans. Electrochem. Soc. 75, 473 (1939).

[16] T. K. Rose, J. Inst. Metals 8, 123 (1912).

[17] A. L. Norbury, Trans. Faraday Soc. 19, 140 (1923).

Washington, September 25, 1945. 